\title{
Weed Control in Chickpea Crops in Lower Volga
}

\section{T V Ivanchenko and A V Belikina}

FSC of Agroecology RAS, Federal State Budget Scientific Institution "Federal Scientific Centre of Agroecology, Complex Melioration and Protective Afforestation of the Russian Academy of Sciences", Volgograd, Russia

\section{Abstract}

Chickpea is a cheap source of nutrients and does not require special soil conditions of growth. In addition, the properties of the symbiotic relationship of nitrogen-containing bacteria in its root system make it a valuable crop for agriculture. Due to its droughtresistant properties, it is one of the most dynamically developing cultures in export potential, which allows producers making profitable trading operations in foreign food markets and improving their financial condition. The climatic conditions of the Russian Federation make it possible to grow chickpeas and produce its seeds. The cultivated areas of chickpea in Russia in 2018, according to Russian Statistic Agency,

Corresponding Author:

T V Ivanchenko

tvivanchenko@bk.ru

Received: 25 October 2019

Accepted: 15 November 2019

Published: 25 November 2019

Publishing services provided by Knowledge E

(c) T V Ivanchenko and A V Belikina. This article is distributed under the terms of the Creative Commons

Attribution License, which permits unrestricted use and redistribution provided that the original author and source are credited.

Selection and Peer-review under the responsibility of the AgroSMART 2019 Conference Committee.
G OPEN ACCESS amounted to 851.2 thousand hectares. Over the year, they increased by $71.6 \%$, from 2013 -- by $26.5 \%$. Volgograd region in the all-Russian chickpea field occupies $22.5 \%$ after the Saratov region, on yield it occupies the seventh position after the Stavropol Territory -- $7.7 \mathrm{c} / \mathrm{ha}$. Chickpea is a valuable crop, the cultivation of which will make it possible to obtain grain beans that are valuable for human food and to engage Russian agricultural producers in export operations. However, weed vegetation reduces the efficiency of chickpea production. The article describes a method of dealing with weed vegetation in chickpea crops in dry conditions. This will allow the use of tank mixtures of herbicides, which are cheaper in cost and effective in combating weeds in chickpea crops. Using this method, it is possible to get a crop without spending extra funds and achieve a profitability of 15 and $25.6 \%$.

Keywords: chickpea, weed vegetation, arid conditions, herbicides, profitability.

\section{Introduction}

Leguminous crops are valuable sources for human nutrition and use in animal husbandry in the preparation of feed for farm animals [1, 2]. Chickpea is one of the most valuable crops containing essential amino acids, dietary fiber, a number of vitamins, minerals and biologically active compounds [3]. Chickpea -- an innovative culture [4], which came from the countries of the Mediterranean [5], Central Asia and North Africa, is able to withstand the arid conditions of Russian regions. Being a cheap source of nutrients, chickpeas are not picky about soil growing conditions, the properties of the symbiotic 
relations of nitrogen-containing bacteria in its root system make it a valuable crop for agriculture [6]. Due to its drought tolerance, it is one of the most dynamically growing crops and increases export potential, which allows producers making profitable trading operations in foreign food markets. The climatic conditions of the Russian Federation make it possible to grow chickpeas and the production of its seeds is developing dynamically. In addition, Russia is one of the exporters of chickpea seeds, although it ranks 19th in 20 exporting countries after Saudi Arabia.

However, all the positive qualities of chickpea have not yet given it wide distribution, including due to the low competitiveness of plants of this crop to weeds [5.6]. It is known that chickpeas do not tolerate the treatment of crops with herbicides [6, 7]; this technological side served for research in the selection of measures to combat weeds. Known methods of combating chemical methods, one of the components is with the addition of prometrin in the Azov Sea Region [9], however, in the Lower Volga region, tank weed herbicide mixtures were studied for the first time.

\section{Methods and Equipment}

\subsection{Methods}

\subsubsection{Soil and climatic conditions of the experiment}

Studies were conducted in 2015--2018. in the experimental field NVNIISH -- branch of the Federal Science Center for Agroecology RAS.

The studies were conducted on the experimental field NVNIISH -- a branch of the Federal Science Center for Agroecology of the Russian Academy of Sciences, located in the light-chestnut subzone of the dry-steppe zone of chestnut soils of the Lower Volga region. The territory is a low-wavy plain. The climate is sharply continental, SCC $=0.5--0.6$. The sum of average daily positive air temperatures is $3400--3500{ }^{\circ} \mathrm{C}$. The average annual rainfall is $300--350 \mathrm{~mm}$. The amplitude of the minimum and maximum temperatures is $7.8^{\circ} \mathrm{C}$ (from +43 to $-35^{\circ} \mathrm{C}$ ).

Soils are low in nitrogen, medium in phosphorus and increased in potassium. The humus content is $1.2--2.0 \%, \mathrm{pH}=7--8$.

Equal crops, crop rotation hospitals and fields of short-term field experiments are located on an area of about 400 hectares. The main types of crop rotations are grain, grain and steam-farming with the number of fields from 2 to 5 . 
There are also biologized grain-fed crop rotations with the number of fields from 4 to 8 and with different saturation with perennial legume grasses and annual leguminous crops. The experimental field is bordered by perennial forests of varying density. Part of the valley is subjected to tinning, a mixture of perennial cereal and legumes. In general, the experimental field has all the characteristic features of a typical dry-steppe agrolandscape.

The humus content was $1.68 \%$, for all variants it was $3.26 \%$, nitrogen, phosphorus9.86, potassium-43.16, Almost at the same level, for all variants of the experiment.

The object of study -- plots -- $150 \mathrm{~m}^{2}$, accounting -- $50 \mathrm{~m}^{2}$. The repetition of the experiment is fourfold. A variety of Privo 1 was sown. In weeds of chickpea weed vegetation, which consisted of amaranth thrown back, amaranth blitoides, chamomile, Mari white, sow thistle, millet chicken, shepherd's bag. Crops were processed in the following way: one version of the experiment with tank mixtures of herbicides containing prometrin active substances in the amount of $750 \mathrm{~g} / \mathrm{ha}$, metribuzin $360 \mathrm{~g} / \mathrm{ha}$, C-metal chloro $786 \mathrm{~g} / \mathrm{ha}$. In another embodiment, the herbicide was mixed with the active ingredient prometrin in the amount of $750 \mathrm{~g} / \mathrm{ha}$ and $786 \mathrm{~g} / \mathrm{ha}$ of C-metolachlor. One option was also left without treatment as a control and comparison with the treated areas (Table 3).

Agrotechnics, with the exception of the factors studied, are generally accepted for the zone of the Lower Volga region. The experiment provides double treatment with growth regulators and microelements: presowing treatment of seeds and the following: processing of crops in the budding and flowering phase.

\subsubsection{Diagrammatic representation}

TABLE 1: Agrochemical analysis data of the arable horizon, 2015--2018.

\begin{tabular}{|c|c|c|c|c|}
\hline Humus, \% & $\mathrm{pH}$ & $\mathrm{mg} / 100 \mathrm{~g}$. \\
\hline & & $\mathrm{NO}_{3}$ & $\mathrm{P}_{2} \mathrm{O}_{5}$ & $\mathrm{~K}_{2} \mathrm{O}$ \\
\hline 1.68 & 7.49 & 3.26 & 9.86 & 43.16 \\
\hline
\end{tabular}

\section{Results}

The aim of the research was to determine the most effective treatment options for tank mixtures of herbicides in combating weed vegetation in chickpea crops on light chestnut soils and the result of which will not reduce the quality of chickpea beans, and 
TABLE 2: Soil granulometric composition in 2015-2018.

\begin{tabular}{|l|c|c|c|c|c|c|c|}
\hline $\begin{array}{l}\text { Genetic } \\
\text { horizon }\end{array}$ & $\begin{array}{c}\text { Sampling } \\
\text { depth, } \mathrm{m}\end{array}$ & \multicolumn{7}{|c|}{ Content of fractions in \%. from abs. dry soil } \\
\hline & & $1-0.25$ & $0.25-0.5$ & $0.05-0.01$ & $0.01-0.005$ & $0.005-0.001$ & 0.001 \\
\hline Aпах & $0-0,20$ & 0.51 & 32.3 & 21.1 & 12.7 & 17.9 & 27.6 \\
\hline В 1 & $0.20-0.35$ & 0.22 & 14.5 & 15.8 & 9.3 & 15.8 & 25.3 \\
\hline В 2 & $0.35-0.65$ & 0.21 & 17.6 & 18.0 & 8.8 & 18.3 & 24.4 \\
\hline
\end{tabular}

TABLE 3: Experience Diagram.

Var. 1

Control (w/r)
Var. 2 (a.m.)

prometrine, $750 \mathrm{~g} / \mathrm{ha}+$ metribuzina $360 \mathrm{~g} / \mathrm{ha}$

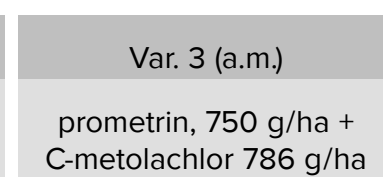

growing chickpea will be cost-effective. One of the main conditions for placing a crop in a crop rotation for sowing is the selection of a field with low weed infestation and the absence of perennial dicotyledonous weeds, since one of the main problems in the technology of cultivation of leguminous crops is weed control. At the beginning of the growing season, chickpea develops the root system, and then the ground mass, so it competes weakly with weeds. The size of crop losses depends on the phase of crop development, clogging density, and the variety of weeds.

Characteristics of drugs used in the experiment:

- Shansgard, KS (ai $500 \mathrm{~g} / \mathrm{l}$ prometrin) -- herbicide for the destruction of annual dicotyledonous and cereal weeds in crops. With pre-emergence application (spraying of the soil), prometrin penetrates into weeds through the root system, and during postemergence through the leaves, thereby blocking the process of photosynthesis.

- Zenkshan, KS (600 g/l metrobuzina) -- selective pre-emergence and postemergence herbicide, for controlling annual and cereal weeds. The action is based on the inhibition of the transport of electrons involved in photosynthesis. Zenanshans are mainly absorbed by weed roots, but can penetrate the plant and through the leaves. Moves acropetally, i.e. down up.

- Dushans, CE (960 g/l C-metolachlor) -- pre-emergence herbicide against annual cereal and some dicotyledonous weeds. Blocks the process of weed regrowth. Cmetolachlor in annual cereal weeds (chicken millet, bristles) penetrates through the coleoptile, then the weed germ is twisted and dies. In dicotyledonous weeds (shchiritsy, mary white, chamomile, shepherd's bag), the herbicide gets through the cotyledons, causing their death, i.e. C-metolachlor absorbed in the germination phase of weeds, thereby causing death, before the emergence of their shoots. 
For the studies, tank mixtures of herbicides based on the active ingredients: prometrin, $750 \mathrm{~g} / \mathrm{ha}$ + metribuzin $360 \mathrm{~g} / \mathrm{ha}$ and prometrin $750 \mathrm{~g} / \mathrm{ha}$ + C-methyl chloro $786 \mathrm{~g} / \mathrm{ha}$ were made. Soil treatment with herbicides was carried out immediately after sowing chickpeas. The flow rate of the working fluid was $200 \mathrm{l} / \mathrm{ha}$.

TABLE 4: Chickpea yield structure, protein content of chickpea depending on the use of herbicides in studies of 2015--2018.

\begin{tabular}{|c|c|c|c|c|c|}
\hline Option & $\begin{array}{l}\text { Qty beans on } \\
\text { one plant, } \\
\text { pieces }\end{array}$ & $\begin{array}{l}\text { Qty seed in a } \\
\text { bean, pieces }\end{array}$ & $\begin{array}{l}\text { Weight } 1000 \\
\text { seeds gr. }\end{array}$ & $\begin{array}{c}\text { Productivity, } \\
\text { t/ha }\end{array}$ & $\begin{array}{l}\text { Content } \\
\text { squirrel, \% }\end{array}$ \\
\hline Var. 1 Control (w/r) & 15.6 & 1.0 & 242.0 & 0.45 & 28.2 \\
\hline $\begin{array}{l}\text { Var. } 2 \text { (a.m.) prometrine, } 750 \\
\mathrm{~g} / \mathrm{ha}+\text { metribuzina } 360 \mathrm{~g} / \mathrm{ha}\end{array}$ & 18.9 & 1.3 & 267.6 & 0.68 & 28.9 \\
\hline $\begin{array}{l}\text { Var. } 3 \text { (a.m.) prometrin, } 750 \\
\text { g/ha + C-metolachlor } 786 \\
\text { g/ha }\end{array}$ & 17.5 & 1.3 & 277.4 & 0.71 & 28.7 \\
\hline \multicolumn{6}{|c|}{ SMD (abs.) 0.05} \\
\hline
\end{tabular}

\section{Discussion}

In our experiments, variant 3 was the most fruitful (prometrin $750 \mathrm{~g} / \mathrm{ha}+\mathrm{C}$-metal chlorine $786 \mathrm{~g} / \mathrm{ha}$ ) -- $0.71 \mathrm{t} / \mathrm{ha}$, which is $57.7 \%$ more than the control variant No. 1. The output of chickpea on variant No. 2, amounted to $0.68 \mathrm{t} / \mathrm{ha}$ and surpassed the yield indicators by $51.1 \%$., In comparison with option No. 1 .

The studies have shown that the amount of protein in variants No. 2-3 slightly exceeded the control variant No. 1 (Table 4).

Chickpeas -- food culture and commodity producers, engaged in growing chickpeas, chooses a competitive focusing strategy, i.e. focuses on chickpea production, occupying a market niche for a specific customer. The political situation in the countries-producers of Australia, the Middle East -- Syria, and the growing population of Turkey, Pakistan, and India, where chickpeas are widely used in the diet, can also be pushed up on price increases. Today the market price in the Southern Federal District at the end of 2018 was 21,300 rubles.

Occupying the seventh place in the national production of chickpeas, Volgograd farmers have the opportunity to strengthen their positions in food markets and increase their income by preventing crop losses due to weeds.

In our experience, in the second variant, the yield increase compared to the control variant was $0.23 \mathrm{t} / \mathrm{ha}$, and the second option allowed us to obtain $0.26 \mathrm{t} / \mathrm{ha}$. Accordingly, 
the second option will provide additional revenues of 4899 rubles, the third option of experience -- 5583 rubles (Table 5).

TABLE 5: Economic efficiency of chickpea cultivation, NVNIISH, a branch of the Federal Science Center for Agroecology RAS in 2015-2018.

\begin{tabular}{|c|c|c|c|}
\hline \multirow[t]{2}{*}{ Indicators } & \multicolumn{3}{|c|}{ Options } \\
\hline & Var. 1 Control (w/r) & $\begin{array}{c}\text { Var. } 2 \text { (a.m.) } \\
\text { prometrin, } 750 \mathrm{~g} / \mathrm{ha} \\
+ \text { metribuzin } 360 \\
\mathrm{~g} / \mathrm{ha}\end{array}$ & $\begin{array}{l}\text { Var. } 3 \text { (a.m.) } \\
\text { prometrin, } 750 \mathrm{~g} / \mathrm{ha} \\
\text { + C-metolachlor } 786 \\
\text { g/ha }\end{array}$ \\
\hline Productivity, t/ha & 0.45 & 0.68 & 0.71 \\
\hline Selling price, $R U B / t$ & 21300 & 21300 & 21300 \\
\hline Proceeds from sales, rubles & 9585 & 14484 & 15123 \\
\hline Material and cash costs, rubles & 10587.0 & 12598.5 & 12041.9 \\
\hline Profit, rubles & --1002 & 1885.5 & 3081.1 \\
\hline Profitability, \% & -- & 15.0 & 25.6 \\
\hline
\end{tabular}

\section{Conclusion}

The conclusions of the research:

1. During the growing season, $100 \%$ efficiency of the herbicide tank mixtures was observed: prometrin, $750 \mathrm{~g} / \mathrm{ha}+$ metribuzin $360 \mathrm{~g} / \mathrm{ha}$ and prometrin $750 \mathrm{~g} / \mathrm{ha}+\mathrm{C}$-metal chlorine $786 \mathrm{~g} / \mathrm{ha}$.

2. On option No. 2--3, Where the herbicidal composition of prometrin $750 \mathrm{~g} / \mathrm{ha}+$ C-metallochlor $786 \mathrm{~g} / \mathrm{ha}$ was used, a positive trend can be traced -- a yield increase of 51.1--57.7 \% was obtained, despite difficult dry conditions in the studies of 2015--2018.

3. Cereal and dicotyledonous weeds at the beginning of chickpea development can cause significant damage to the crop. In order to prevent the germination of weeds, it is necessary to use tank mixtures of soil herbicides. Metribuzin and C-metolachlor mainly destroy cereal weeds, work worse against dicotyledonous weeds, and therefore it is necessary to add another active ingredient, such as prometrin, since it effectively destroys dicotyledon weeds. As a result of research, these tank mixes with prometrin have shown high efficiency.

4. In the experiment, the most economically efficient option is with a prometrin 750 $\mathrm{g} / \mathrm{ha}$ tank herbicide mixture $+786 \mathrm{~g} / \mathrm{ha}$ metallochloride $--25.6 \%$, with a chickpea yield of $0.71 \mathrm{t} / \mathrm{ha}$. 
Thus, as a result of research, it was determined that tank mixtures of herbicides are effective in combating weeds in chickpea crops and yields can be obtained with a profitability of 15 and $25.6 \%$, which allows significantly improving the financial condition of farms and soil fertility in crop rotations, which are sown set of crops.

\section{Funding}

The research was performed according to task of FSC of Agroecology RAS, Federal State Budget Scientific Institution "Federal Scientific Centre of Agroecology, Complex Melioration and Protective Afforestation of the Russian Academy of Sciences" № 07132018-0011.

\section{Acknowledgement}

The authors would like to thank their colleague for their contribution and support to the research. They are also thankful to all the reviewers who gave their valuable inputs to the manuscript and helped in completing the paper.

\section{Conflict of Interest}

The authors have no conflict of interest to declare.

\section{References}

[1] Kononenko, S.I., Meshcheryakov, AG, Levakhin, Yu.I., Ispanova, A.M. (2015). Comparative assessment of the nutritional benefits of grain of peas and chickpeas of different varieties in drought conditions. Scientific journal KubGAU -- Scientific Journal of KubSAU, no. 107.

[2] Ponomarev, E.I., Lukina, S.I., Kustov, V.V., Gabelko, E.A. (2017). Justification of the rational moisture content of wheat bread, enriched with oat bran flour. Herald VSUIT., no. 2(72).

[3] Vishnyakova, M.A., Burlyaeva, M.O., Bulyntsev, S.V., Seferova, I.V., Plekhanova, E.S., Nuzhdin, S.V. (2017). Local varieties of chickpeas from centers of cultural origin: diversity and differences. Agricultural Biology, no. 5.

[4] Molchanova, E.N., Shipareva, MG, Li, E.V., Karelina, N.N. (2018). Innovations in the use of pulses. Nutrition issues. Volume 87, No. 5, 2018. Appendix. Materials of the XVII 
All-Russian Congress with international participation "Fundamental and applied aspects of nutriciology and nutrition. Medical, preventive and sports nutrition" (Moscow, 29--31 October 2018).

[5] Vishnyakova, M.A., Aleksandrova, T.G., Bulyntsev, S.V., Buravtseva, T.V., Burlyaeva, M.O., Egorova, G.P., Semenova, E.V., Seferova, I.V., Yankov, I.I. (2016). Mediterranean leguminous genetic resources in the VIR collection: diversity and use (review). Agricultural Biology, no. 1.

[6] Demchenko, MV, (2011) The yield and feed value of the products of mixed crops of chickpea with barley. Proceedings of the Orenburg State Agrarian University, no. 29(1), pp. 42--44.

[7] Didovich, S.V., Gorgulko T.V., Alekseenko O.P. (2017). Potential of plant-microbial interaction in agrocenoses of leguminous crops. News OGAU, no. 4(66).

[8] Dzhirgalova, Ye.A., Frolov, NN, Konsago, F. (2016). Influence of the herbicide on weed vegetation death in chickpea crops cultivated under the conditions of the Ukrainian Scientific and Practical Center "Agronomus" of Kalmyk State University. Innovative science, no. 4--3.

[9] Radevich, E.V. (2016). The effect of chemical treatments on chickpea clogging. News OGAU, no. 3(59).

[10] Bulyntsev, S.V., Novikova, L.Yu., Gridnev, G.A., Sergeev, E.A. (2015). Correlations of breeding traits that determine the productivity of chickpea samples (Cicer arietinum L.) from the collection VIR in the conditions of the Tambov region. Agricultural Biology, no. 1. 